\title{
Penyuluhan Pembuatan Pupuk Organik Cair Eceng Gondok dan Keong Mas sebagai Upaya Pemberdayaan bagi Ibu PKK di Desa Tlompakan Kabupaten Semarang
}

\author{
Muhimmatul Ifadah ${ }^{1} *$, Rafaella C. Megananda ${ }^{2}$, Nabilatus Sunayya ${ }^{3}$, \\ Afni Harfina ${ }^{4}$, Florentina Kusmiyati ${ }^{5}$ \\ ${ }^{1 *, 5}$ Agroekoteknologi, FPP, Universitas Diponegoro \\ ${ }^{2,4}$ Teknologi Pangan, FPP, Universitas Diponegoro \\ ${ }^{3}$ Teknologi Hasil Perikanan, FPIK, Universitas Diponegoro \\ *Corresponding Author. Email: muhimatulifada63@gmail.com
}

\begin{abstract}
The purpose of this community service activity is to increase the insight of PKK Dusun Semen on the process of processing liquid organic fertilizer from water hyacinth and golden snail. Water hyacinth and golden snail are used as basic ingredients for making liquid organic fertilizer because they are abundant and have potential as liquid organic fertilizer. Extension activities were carried out using the lecture method and Focussed Group Discussion (FGD). Based on the counseling activities that have been carried out, Ms. PKK has begun to understand the stages of the process of making liquid organic fertilizer from water hyacinth and golden snail. The support from the head of the PKK and the enthusiasm of Mrs. PKK were seen during the extension activities.
\end{abstract}

Article History:

Received: 26-07-2021

Reviewed: 21-08-2021

Accepted: 10-09-2021

Published: 13-11-2021

\section{Key Words: \\ Counseling, Rawa \\ Pening, Liquid \\ Organic Fertilizer.}

\section{Sejarah Artikel:}

Diterima: 26-07-2021

Direview: 21-08-2021

Disetujui: 10-09-2021

Diterbitkan: 13-11-2021

\section{Kata Kunci:}

Penyuluhan, Rawa

Pening, Pupuk Organik

Cair.

How to Cite: Ifadah, M., Megananda, R., Sunayya, N., Harfina, A., \& Kusmiyati, F. (2021). Penyuluhan Pembuatan Pupuk Organik Cair Eceng Gondok dan Keong Mas sebagai Upaya Pemberdayaan bagi Ibu PKK di Desa Tlompakan Kabupaten Semarang. Jurnal Pengabdian UNDIKMA, 2(2), 166-174. doi:https://doi.org/10.33394/jpu.v2i2.4002

https://doi.org/10.33394/jpu.v2i2.4002

This is an open-access article under the CC-BY-SA License.

\section{Pendahuluan}

Salah satu indikator peningkatan taraf kesejahteraan suatu wilayah adalah tingkat kesejahteraan perempuan terutama di bidang ekonomi. Perempuan memiliki peran yang penting dalam peningkatan kesejahteraan keluarga. Keterampilan merupakan salah satu pokok penting yang harus dimiliki perempuan disamping tingkat pendidikan serta kebebasan dalam menentukan pekerjaan serta berorgarnisasi dan mengemukakan pendapat. Wadah yang paling umum untuk perempuan yang telah menikah adalah PKK (Pembinaan Kesejahteraan Keluarga).

Dusun Semen terletak di Kecamatan Tuntang, Kabupaten Semarang dengan jumlah penduduk 110 KK. Dusun Semen memiliki total luas wilayah $317.285 \mathrm{~m}^{2}$ sebesar $83.600 \mathrm{~m}^{2}$ merupakan wilayah pemukiman sedangkan sisanya merupakan area lahan pertanian dan hutan. Sebagian besar masyarakat bermata pencaharian sebagai petani yang didominasi oleh 
laki-laki. Perempuan di dusun Semen umumnya hanya bekerja sebagai ibu rumah tangga dan tidak mempunyai penghasilan secara mandiri karena kurangnya pendidikan dan keterampilan yang dimiliki. Kegiatan yang biasa dilakukan ibu PKK dusun Semen adalah senam setiap sabtu pagi dan pengelolaan bank sampah. Pengelolaan bank sampah tidak berjalan dengan optimal selama masa pandemi karena adanya pemberlakuan pembatasan kegiatan masyarakat.

Salah satu upaya untuk memberikan keterampilan pada Ibu PKK dusun Semen dikala pandemi adalah penyuluhan keterampilan secara daring. Penyuluhan yang dilakukan oleh tim PKM PM Universitas Diponegoro mengangkat pembahasan bagaimana proses pembuatan pupuk organik cair berbahan dasar eceng gondok dan keong mas. Hal ini disebabkan oleh keberadaan eceng gondok di Rawa Pening yang sangat melimpah serta keong mas di area persawahan masyarakat dusun Semen yang belum dimanfaatkan. Rawa Pening adalah rawa yang dimanfaatkan untuk kegiatan wisata yang terletak di Kabupaten Semarang dan termasuk sebagai danau alam dengan luas 2380 Ha. Namun, kondisi terkini Rawa Pening mengalamai hipereutrofikasi (Sur et al., 2014). Salah satu faktor yang menyebabkan adanya permasalahan pada danau Rawa Pening adalah kualitas perairan. Degradasi kualitas air, sedimentasi yang cukup tinggi, serta melimpahnya eceng gondok dapat mengakibatkan proses pendangkalan danau yang dipercepat. Tahun 2017, danau Rawa Pening mengalami perubahan penyempitan permukaan air danau sebesar $8,3 \%$. Status mutu air tergolong tercemar berat dan akibatnya terjadi hilangnya fauna dan flora endemik asli (Suryanto et al., 2020). Tumbuhan air yang menurupi permukaan yang tidak terkendali mengganggu fungsi danau serta terjadinya blooming di beberapa area danau terutama pada bagian yang mengandung unsur fosfor, klorofil, dan total nutrient yang tinggi (Heriza et al., 2018).

Populasi eceng gondok yang terdapat di danau Rawa Pening dapat mengalami peningkatan terutama pada musim kemarau dapat mencapai 70\% (Heriza et al., 2018). Eceng gondok merupakan tumbuhan air yang dianggap sebagai gulma karena dapat menyebabkan beberapa kerugian seperti mempercepat pendangkalan, penyumbatan saluran irigasi, penurunan hasil perikanan, dan memperbesar terjadinya kehilangan air melalui proses evapotranspirasi (Heriza et al., 2018). Pertumbuhan eceng gondok yang tidak terkendali akan menyebabkan terjadinya defisit oksigen $\left(\mathrm{O}_{2}\right)$ dan terganggunya proses nitrifikasi. Hal tersebut jika terjadi secara terus menerus dapat dikhawatirkan akan terjadi potensi bahaya pendangkalan organik dari Eceng Gondok dan hambatannya yang berbahaya (Purwandari et al., 2013).

Berdasarkan hasil observasi, pada area pertanian di Rawa Pening ditemukan adanya keong mas yang sangat melimpah. Menurut Alfathir (2019), setiap $100 \mathrm{~m}^{2}$ terdapat $1 \mathrm{~kg}$ keong mas (Pomacea canliculata L.). Keong mas (Pomacea canaliculata L.) merupakan hama yang merusak tanaman padi dengan cara memakan seluruh batang tanaman padi dalam waktu yang relatif cepat (satu malam) (Liunokas et al., 2019). Dampaknya adalah rumpun tanaman padi hilang dan dapat mengakibatkan gagal panen. Oleh karena itu, dibutuhkan cara untuk menanggulangi hama keong mas (Satiyarti et al., 2019).

Pengolahan lahan pertanian di desa Tlompakan masih menggunakan pupuk anorganik. Penggunaan pupuk anorganik yang berlebihan dapat merusak sifat fisik, kimia, dan biologi tanah serta dapat menghambat kerja mikroorganisme dalam tanah. Bahan kimia yang masih tertinggal di dalam tanaman dan terangkut saat panen juga dapat membahayakan kesehatan manusia (Ramadhan dan Sumarni, 2018). Oleh karena itu diperlukan kesadaran petani mengenai pentingnya penggunaan pupuk organik. Limbah eceng gondok dan hama keong mas dapat dimanfaatkan menjadi pupuk organik cair karena mengandung unsur $\mathrm{C}, \mathrm{N}$, 
$\mathrm{P}$, dan $\mathrm{K}$ yang dibutuhkan tanaman dalam pemenuhan unsur hara (Yuliatin et al., 2018). Potensi ini dapat dikembangkan menjadi sektor pertanian berkelanjutan dalam rangka menjaga ketahanan pangan di masa pandemi. Pemberdayaan ibu-ibu PKK yang dilakukan dalam mengolah eceng gondok dan keong mas menjadi pupuk organik cair dapat membantu mewujudkan Sustainable Development Goals poin 8 yaitu pekerjaan layak dan pertumbuhan ekonomi, poin 14 ekosistem perairan, dan poin 15.

Berdasarkan uraian di atas, kegiatan pengabdian yang dilakukan memiliki beberapa tujuan diantaranta adalah meningkatkan pengetahuan serta keterampilan Ibu PKK mengenai pengolahan limbah eceng gondok dan keong mas menjadi pupuk organik cair. Ibu PKK yang sudah memiliki keterampilan dalam mengolah eceng gondok dan keong mas menjadi pupuk organik cair, maka pupuknya dapat digunakan sebagai pupuk untuk area pertanian masyarakat. Program yang dijalankan nantinya juga diharapkan mampu menjadi ide usaha bagi ibu rumah tangga.

\section{Metode Pengabdian}

Kegiatan pengabdian dilaksanakan di Dusun Semen, Kecamatan Tuntang, Kabupaten Semarang Jawa Tengah yang dilakukan oleh mahasiswa Universitas Diponegoro Semarang. Kegiatan ini berjalan dengan adanya kerjasama dengan Ibu PKK Dusun Semen. Kegiatan pengabdian yang dilaksanakan selama 4 bulan sejak bulan Juni 2021-September 2021. Kegiatan pengabdian ini dilakukan dengan metode penyuluhan berupa ceramah dan Focussed Group Disscusion yang terdiri dari beberapa tahapan diantaranya:

\section{1) Observasi Lapangan}

Kegiatan observasi ini dilakukan untuk mengetahui kondisi mitra secara pasti dan dilakukan juga wawancara secara singkat terhadap mitra. Kegiatan observasi lapangan bertujuan untuk menentukan metode penyuluhan dan gaya penyuluhan yang digunakan agar mitra menangkap dan dapat mengikuti kegiatan dengan baik. Kegiatan observasi juga diikuti dengan kegiatan menjalin komunikasi dengan perangkat Dusun Semen agar program pengabdian dapat dilakukan dengan baik.

\section{2) Persiapan}

Tahap persiapan tim melakukan penyusunan materi mengenai pemanfaatan eceng gondok dan keong mas menjadi pupuk organik cair. Penyusunan materi dilakukan dengan media microsoft power point yang akan ditampilkan saat kegiatan penyuluhan. Kegiatan ini juga diikuti dengan pembuatan kuisioner yang akan diisikan sebelum penyuluhan menggunakan google form. Adapun pertanyaan yang digunakan adalah sebagai berikut:

a) Apakah ibu-ibu mengetahui bahwa eceng gondok dan keong mas yang dikombinasikan dapat diolah menjadi pupuk organik cair? (ya/tidak)

b) Apakah ibu-ibu mengetahui jenis plastik yang digunakan sebagai kemasan pupuk organik cair? (ya/tidak)

c) Apakah ibu-ibu mengetahui bahwa sosial media dapat digunakan untuk kegiatan pemasaran? (ya/tidak)

\section{3) Penyuluhan}

Kegiatan penyuluhan dilaksanakan secara daring dengan media zoom meeting yang diikuti oleh tim, Ibu PKK dan dosen pendamping. Kegiatan penyuluhan ini berjalan selama 90 menit dengan agenda penyampaian penyuluhan mengenai pemanfaatan eceng gondok dan keong mas sebagai pupuk organik cair. Dalam kegiatan penyuluhan juga dijelaskan dan ditayangkan video tutorial pembuatan pupuk organik cair dari eceng gondok dan keong mas hingga proses pengemasan, pelabelan dan pemasaran pupuk organik cair. 


\section{d) Evaluasi}

Tahap evaluasi dilakukan untuk mengukur keberhasilan program penyuluhan yang telah diberikan tim kepada Ibu PKK. Evaluasi yang dilakukan dengan analisis secara deskriptif hasil kuisioner yang telah diisikan oleh Ibu PKK sebelum dan sesudah kegiatan yang telah dilakukan. Adapun pertanyaan yang diberikan sebagai bahan evaluasi melalui google form adalah sebagai berikut:

a) Apakah ibu-ibu sudah paham cara mengolah eceng gondok dan keong mas menjadi pupuk organik cair?

b) Apakah ibu-ibu sudah paham cara pengemasan dan pelabelan pupuk organik cair dari eceng gondok dan keong mas?

c) Apakah ibu-ibu sudah paham cara mengoperasikan website dan instagram sebagai media pemasaran?

\section{Hasil Pengabdian dan Pembahasan}

Hasil yang diperoleh dari masing-masing kegiatan adalah sebagai berikut:

1) Observasi Lapangan

Observasi dilaksanakan dengan pemantauan secara langsung di lokasi, yakni wilayah Dusun Semen yang terletak tidak jauh dari kawasan Rawa Pening Kecamatan Tuntang Kabupaten Semarang. Hasil pengamatan langsung yang telah dilaksanakan ditemukan bahwa jumlah eceng gondok yang tumbuh di area Rawa Pening sangat luas dan berpotensi mengganggu ekosistem di dalamnya. BLH Kabupaten Semarang melakukan pembersihan eceng gondok secara berkala namun pertumbuhan eceng gondok relatif cepat dan menghambat mobilitas kegiatan nelayan. Batang eceng gondok umumnya dimanfaatkan oleh masyarakat sebagai bahan pembuatan kerajinan anyaman sedangkan daun dan akarnya tidak dimanfaatkan. Masyarakat pada umumnya tidak mengetahui ancaman lingkungan akibat keberadaan eceng gondok yang tidak terkontrol. Permasalahan lain datang dari sektor pertanian yakni keberadaan keong mas yang umumnya mengganggu tanaman utama. Keong mas yang tumbuh dan berkembang biak di area pertanaman padi menyebabkan jumlah anakan yang muncul menjadi berkurang dan pada akhirnya berpengaruh pada hasil panen.

Kegiatan observasi juga dilakukan dengan wawancara langsung kepada masyarakat dan tokoh masyarakat yaitu kepala desa, PKK, dan kelompok tani. Kegiatan observasi terdapat pada Gambar 1. Masyarakat menyatakan bahwa tidak banyak mengetahui tentang potensi eceng gondok dan keong mas sebagai bahan dasar pembuatan pupuk organik cair. Pemanfaatan eceng gondok yang dilakukan oleh masyarakat umumnya juga hanya bagian batang eceng gondok sehingga sebagian besar eceng gondok terbuang menjadi limbah sedangkan untuk keong mas akan dibasmi menggunakan insektisida dan tidak dimanfaatkan sama sekali. Para tokoh masyarakat menjelaskan bahwa masyarakat tidak dapat memanfaatkan eceng gondok dan keong mas karena tidak mengetahui kandungan apa saja yang terdapat di dalamnya. Penjelasan dari tokoh masyarakat bahwa Ibu-Ibu PKK Dusun Semen juga mengalami kesulitan pemasaran produk terutama di kala pandemi seperti saat ini. Smartphone yang digunakan telah memiliki beragam aplikasi yang dapat dimanfaatkan untuk berjualan secara daring namum Ibu-Ibu PKK tidak mengetahui cara kerjanya. 


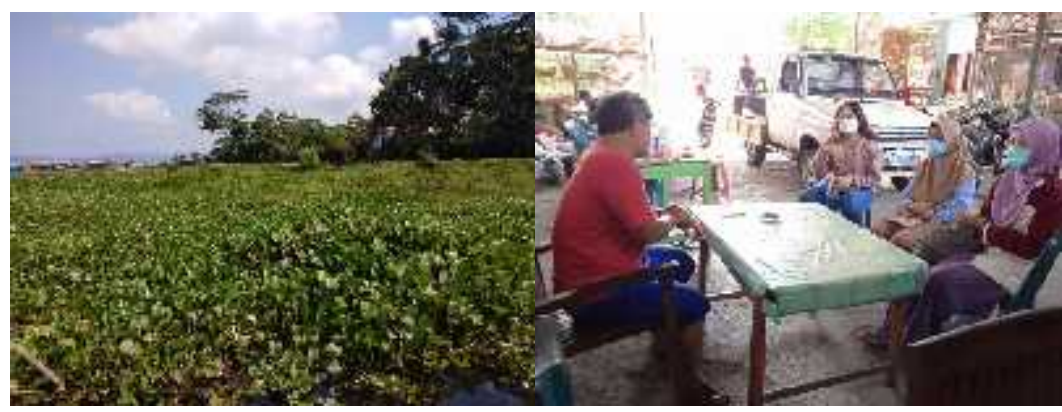

\section{Gambar 1. Kegiatan Observasi di Perairan Rawa Pening dan Kediaman} Tokoh Masyarakat

\section{2) Kegiatan Persiapan}

Kegiatan kedua adalah persiapan meliputi pembuatan video tata cara penggunaan zoom yang mudah dipahami, pembuatan materi penyuluhan serta pembuatan kuisioner sebelum dan sesudah kegiatan. Video tata cara pengoperasian aplikasi zoom yang diberikan adalah khusus perangkat smartphone. Kegiatan pembuatan materi penyuluhan mengenai pemanfaatan eceng gondok dan keong mas serta bahayanya bagi lingkungan dilakukan tim dari tempat tinggal masing-masing dengan mengakses jurnal dan sumber-sumber pendukung melalui internet. Pembuatan kuisioner dilakukan bersamaan dengan editing materi yang telah dikumpulkan.

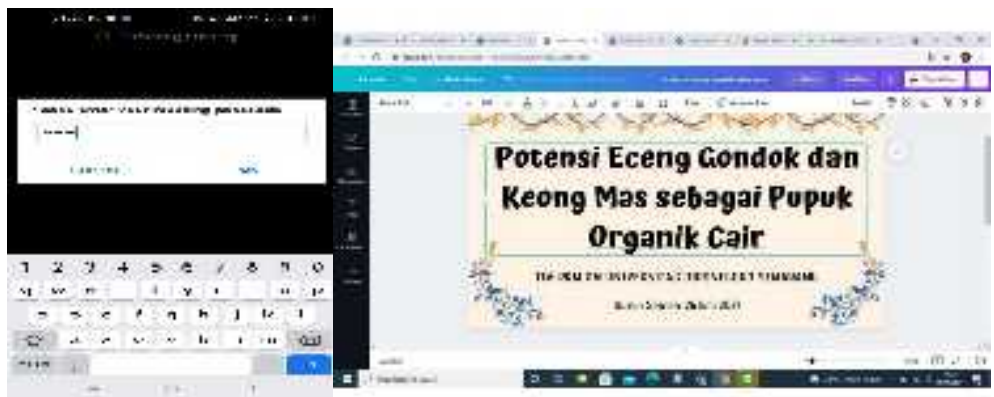

\section{Gambar 2. Persiapan Pembuatan Materi dan Tata Cara Penggunaan Zoom}

\section{3) Kegiatan Penyuluhan}

Metode penyuluhan secara ceramah dan focused group discussion. Materi penyuluhan yang diberikan diantaranya adalah manfaat keong mas dan eceng gondok sebagai bahan pembuatan pupuk organik cair, kemasan plastik yang sesuai untuk pupuk organik cair, serta pemanfaatan media digital untuk berjualan secara daring. Peserta dalam kegiatan penyuluhan merupakan Ibu PKK Dusun Semen, Tuntang dan dihadiri sebanyak 10 orang setiap kegiatan. Peserta penyuluhan sangat antusias selama kegiatan berlangsung dan terlibat aktif dalam berdiskusi. Seluruh peserta mengajukan berbagai pertanyaan terkait manfaat dan kelebihan eceng gondok dan keong mas sebagai pupuk organik cair bagi tanaman serta penggunaan media sosial untuk berjualan dari rumah. Peserta dan tim PKM-PM Universitas Diponegoro serta dosen pendamping saling berbagi pengalaman mengenai penggunaan sosial media serta pemanfaatan eceng gondok dan keong mas yang terdapat di area persawahan Dusun Semen serta Perairan Rawa Pening. 

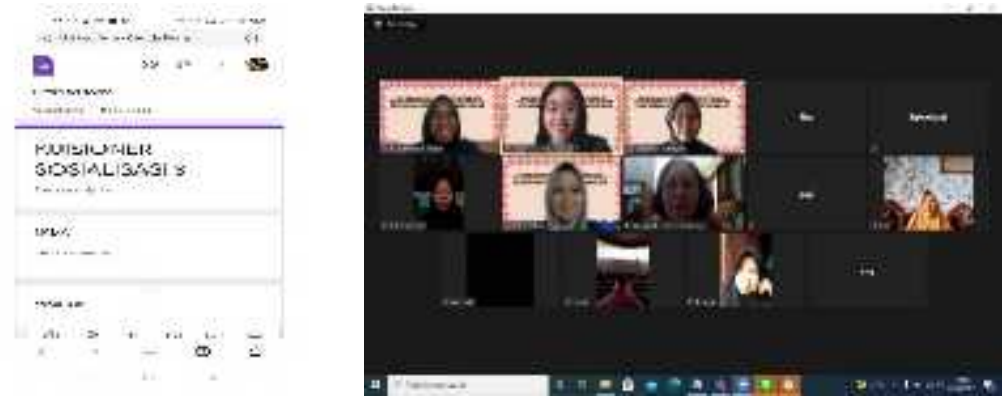

Gambar 3. Kegiatan Penyuluhan Tim dan Dosen Pembimbing dan Tampilan Kuisioner Kegiatan penyuluhan didukung dengan adanya materi dalam bentuk power point serta video recording selama kegiatan sosialisasi berlangsung agar ibu PKK dapat memutar video tersebut tak terbatas ruang dan waktu leaflet sehingga ibu PKK dapat mengikuti kegiatan sosialisasi dengan baik. Berdasarkan hasil observasi, angket, dan kuisioner dapat dijelaskan dalam komponen berikut.

\subsection{Kehadiran Jumlah Peserta}

Anggota ibu-ibu yang mengikuti serangkaian acara penyuluhan daring dikategorikan sangat baik. Target peserta dalam kegiatan ini adalah 10 orang, dalam pelaksanaan kegiatan kehadiran peserta yaitu 10 orang (100\%). Ibu PKK berperan aktif dalam mengikuti sosialisasi secara daring melalui grup Whatsapp dan aplikasi Zoom Meeting seperti menaggapi materi dan mengajukan pertanyaan.

\subsection{Keterlaksanaan Kegiatan}

Pelaksanaan kegiatan merupakan serangkaian kegiatan yang diawali dengan melakukan survey/observasi, koordinasi dengan desa mitra, dan sosialisasi. Perolehan hasil angket, $100 \%$ ibu PKK menyatakan senang dan antusias dalam mengikuti kegiatan, 85\% masyarakat menyatakan berminat untuk menggunakan pupuk organik cair dari eceng gondok dan keong mas, dan $90 \%$ masyarakat mau untuk memanfaatkan eceng gondok dan keong mas menjadi pupuk organik cair.

\subsection{Materi yang Diberikan dalam Penyuluhan}

Ketercapaian materi yang diberikan dikategorikan baik, yaitu 85\%. Semua materi telah dipersiapkan dan direncanakan sehingga dapat disampaikan secara keseluruhan meskipun secara virtual. Hasil angket menunjukkan bahwa 60\% Ibu PKK paham cara mengolah eceng gondok dan keong mas sebagai pupuk organik cair. Sebanyak 80\% Ibu PKK sudah paham cara mengemas dan melakukan pelabelan pupuk organik cair. 60\% Ibu PKK telah paham cara mengoperasikan website dan instagram sebagai media pemasaran.

\section{4) Evaluasi}

Kegiatan keempat yaitu evaluasi yang dilakukan setelah kegiatan penyuluhan dilaksanakan. Evaluasi dilakukan untuk mengetahui tingkat keberhasilan program penyuluhan. Evaluasi dilakukan dengan membandingkan jawaban pertanyaan peserta pada lembar kuisioner sebelum dan sesudah kegiatan penyuluhan. Analisis hasil angket yang dilakukan secara deskriptif menunjukkan bahwa Ibu PKK sudah mulai paham mengenai pengolahan eceng gondok dan keong mas menjadi pupuk organic cair. Kegiatan ini kedepannya dapat dilanjutkan dengan pembuatan pupuk organic cair dari eceng gondok dan keong mas secara mandiri oleh Ibu PKK Dusun Semen.

\subsection{Tingkat Kepuasan Masyarakat Dusun Semen}

Menurut hasil angket yang telah diberikan pada saat akhir kegiatan, sebanyak $90 \%$ ibu PKK menyampaikan puas dengan kegiatan tersebut. Ibu PKK memberi catatan untuk 
menggunakan metode tatap muka dalam penyampaian materi penyuluhan secara agar mudah tersampaikan dan dapat berinteraksi secara langsung. Ibu PKK juga berharap agar kegiatan tersebut dapat dikembangkan dan membantu perekonomian Dusun Semen. Adapun hasil angket dan kategori adalah sebagai berikut.

Tabel 1. Analisis Hasil Angket dan Kategori

\begin{tabular}{ccc}
\hline Kegiatan & Hasil (\%) & $\begin{array}{c}\text { Keterangan } \\
\text { (Prasetyo, 2017) }\end{array}$ \\
\hline Kehadiran peserta & $100 \%$ & Sangat baik \\
\hline Antusiasme peserta dalam mengikuti kegiatan & $100 \%$ & Sangat baik \\
\hline $\begin{array}{c}\text { Minat masyarakat untuk menggunakan pupuk } \\
\text { organik cair dari eceng gondok dan keong } \\
\text { mas }\end{array}$ & $85 \%$ & Sangat baik \\
\hline $\begin{array}{c}\text { Masyarakat mau untuk memanfaatkan eceng } \\
\text { gondok dan keong mas menjadi pupuk } \\
\text { organik cair }\end{array}$ & $90 \%$ & Sangat baik \\
\hline $\begin{array}{c}\text { Ketercapaian materi yang diberikan saat } \\
\text { penyuluhan }\end{array}$ & $85 \%$ & Sangat baik \\
\hline $\begin{array}{c}\text { Pemahaman ibu PKK tentang cara mengolah } \\
\text { eceng gondok dan keong mas sebagai pupuk } \\
\text { organik cair }\end{array}$ & $60 \%$ & Baik \\
\hline $\begin{array}{c}\text { Pemahaman ibu PKK tentang cara mengemas } \\
\text { dan melakukan pelabelan pupuk organik cair }\end{array}$ & $80 \%$ & Baik \\
\hline $\begin{array}{c}\text { Pemahaman ibu PKK tentang cara } \\
\text { mengoperasikan website dan instagram } \\
\text { sebagai media pemasaran }\end{array}$ & $60 \%$ & Sangat baik \\
\hline \begin{tabular}{c} 
Tingkat kepuasan masyarakat \\
\hline
\end{tabular} & $90 \%$ & \\
\hline
\end{tabular}

Kegiatan penyuluhan yang telah dilakukan akan dilanjutkan dengan kegiatan pelatihan dan pendampingan. Ibu PKK yang sudah mulai paham cara pengolahan eceng gondok dan keong mas menjadi pupuk organik cair akan didampingi oleh tim dalam proses pembuatan secara langsung pasca PKKM (pemberlakuan pembatasan kegiatan masyarakat) telah selesai. Kegiatan pelatihan yang akan dilakukan secara langsung diantaranya adalah pelatihan pembuatan puuk organik cair eceng gondok dan keong mas, pelatihan pemasaran menggunakan Instagram, serta branding produk menggunakan website. Penentuan jadwal kegiatan secara rutin juga dilakukan oleh Ibu PKK agar kegiatan dapat berjalan dengan baik dan berkelanjutan sesuai sasaran. Tim juga akan menetapkan penanggung jawab kelompok PKK guna pelatihan secara tatap muka yang akan dilaksanakan kedepannya. Kegiatan pelatihan yang akan dilaksanakan secara tatap muka nantinya dimaksudkan agar Ibu-ibu PKK lebih memahami dengan adanya interaksi tanya jawab serta mitra dapat menerapkan keterampilan dengan praktik secara langsung bersama tim. Program pengabdian yang dilakukan oleh Hunaepi et al., (2017) juga menyatakan bahwa mitra lebih mampu memahami dengan baik teknis pelatihan ketika dilaksanakan secara tatap muka. 


\section{Kesimpulan}

Berdasarkan kegiatan pengabdian yang telah dilaksanakan diperoleh kesimpulan bahwa pengetahuan Ibu PKK Dusun Semen mengalami peningkatan setelah diadakan kegiatan penyuluhan pembuatan pupuk organic cair dari eceng gondok dan keong mas. Kegiatan penyuluhan yang telah dilakukan membawa perubahan pola pikir dan pengetahuan masyarakat mengenai pengolahan pupuk organic cair dari eceng gondok dan keong mas. Keberhasilan program ini ditentukan dengan hasil pupuk organic cair yang berhasil dibuat oleh Ibu PKK.

\section{Saran}

Saran yang disampaikan dari hasil kegiatan pengabdian ini yakni keberlanjutan pembuatan pupuk organik cair eceng gondok dan keong mas oleh Ibu-Ibu PKK di desa Tlompakan memerlukan dukungan banyak pihak diantaranya adalah pemerintah desa. Bentuk dukungan tersebut salah satunya dengan memberikan penyediaan anggaran untuk peralatan awal agar implementasi program dapat dilakukan. Kegiatan pelatihan secara tatap muka juga penting untuk dilaksanakan agar pemahaman yang diterima masyarakat berupa kegiatan secara langsung sehingga mudah dimengerti. Oleh karena itu, dukungan pemerintah desa berupa anggaran peralatan sangat penting guna realisasi pelatihan secara tatap muka. Disarankan pula kepada Tim PKM PM Universitas Diponegoro untuk melakukan pendampingan secara berkala mulai dari proses pembuatan pupuk organik cair, pengemasan, hingga pemasaran kedepannya hal ini dimaksudkan agar pemanfaatan eceng gondok dan keong mas dapat berlangsung secara terus menerus serta menjadi salah satu upaya peningkatan pendapatan Ibu-Ibu PKK desa Tlompakan dan penyelamatan ekosistem perairan Rawa Pening.

\section{Daftar Pustaka}

Alfathir, S. (2017). Inovasi Pengelolaan Hama Keong Mas (Pomacea Canaliculata Lamarck) Menjadi Produk Keripik Keong Mas Polita Di Cv Polita Nusantara (Doctoral dissertation, Universitas Brawijaya).

Heriza, D., Sukmono, A., \& Bashit, N. (2018). Analisis perubahan kualitas perairan Danau Rawa Pening periode 2013, 2015 dan 2017 dengan menggunakan data citra Landsat 8 multitemporal. Jurnal Geodesi Undip, 7(1), 79-89.

Hunaepi., Taufik, S., Laras, F., Baiq, M., Ahmadi., Muhali., Muhammad, A., Irham, A. (2017). Pemberdayaan ibu-ibu PKK melalui pelatihan produksi deterjen cair di desa Sukaraja Lombok Tengah. Jurnal Pengabdian Kepada Masyarakat IKIP Mataram, 2 (1), 65-67.

Liunokas, A. B., Joice. J. Bana \& D. Amalo. (2019). Pengaruh Pemberian Ekstrak Pinang (Areca Catechu L.) terhadap Kesintasan Telur Keong Mas (Pomacea Canaliculata Lamarck). J. Biologi Tropis. 19 (2) : 294-301

Marthana, W. S. M., Soeprobowati, T. R., \& Izzati, M. (2014). Bioakumulasi Timbal (Pb) oleh Hydrilla verticillata Lf Royle di Danau Rawapening, Ambarawa Semarang. Jurnal Sains dan Matematika, 22(2), 52-59.

Nur Ramadhan, A. F., \& Sumarni, T. (2018). Respon tanaman bawang merah (Allium ascalonicum L.) terhadap pupuk kandang dan pupuk anorganik (NPK). Jurnal Produksi Tanaman, 6(5).

Prasetyo, E. B. (2017). Penerapan Model Pembelajaran Savi Menggunakan Media Maket Pada Mata Pelajaran Menggambar Konstruksi Atapdi Kelas Xii-Tgb 2 Smk Negeri Kudu. Jurnal Kajian Pendidikan Teknik Bangunan, 2(2/JKPTB/17). 
Purwandari, Y., Purnomo, P. W., \& Nitisupardjo, M. (2013). Hubungan antara total bakteri dengan bahan organik, NO3 dan H2S pada lokasi sekitar eceng gondok dan perairan terbuka di Rawa Pening. Management of Aquatic Resources Journal (MAQUARES), 2(3), 85-92.

Satiyarti, R. B., Yana, Y., \& Fatimatuzzahra, F. (2019). Penggunaan Ekstrak Daun Jambu Biji (Psidium guajava L.) sebagai Ovisida Keong Mas (Pomacea canaliculata L.). alKimiya: Jurnal Ilmu Kimia dan Terapan, 6(1), 32-35.

Sittadewi, E. H. (2011). Kondisi lahan pasang surut kawasan rawa pening dan potensi pemanfaatannya. Jurnal Teknologi Lingkungan, 9(3).

Suryanto, H., Retnowati, \& Purwanto. 2020. Local Wisdom Management to Maintain the Local Environtment (A Study of the Naga Baru Klinting folklore in Rawa Pening Ambarawa). Journal Of International Conference Proceedings. 3(1) : 116-123.

Yuliatin, E., Sari, Y. P., \& Hendra, M. (2018). Efektivitas Pupuk Organik Cair dari Eceng Gondok (Eichornia crassipes (Mart), Solm) untuk Pertumbuhan dan Kecerahan Warna Merah Daun Aglaonema 'Lipstik'. Biotropika: Journal of Tropical Biology, 6(1), 2834. 